\title{
ZBAWCZY WYMIAR SAMOTNOŚCI ORAZ JEJ KONSEKWENCJE DLA CHRZEŚCIJANINA
}

\section{Otwarcie ukrzyżowanego Boga wobec grzesznika}

Chrystusowy krzyż jest dla Hansa Ursa von Balthasara odpowiedzią człowiekowi, który doświadcza samotności. Dzięki niemu Zbawiciel „zakłóca absolutną samotność, do której dąży grzesznik”, by przed Nim uciec. Bóg na krzyżu solidaryzuje się jednak z tym, który skazuje siebie na potępienie. Bóg nie umiera, bo zawsze nadaje sens życiu, otwierając ludzkie dusze, by wprowadzić je na spotkanie ze Sobą, oraz jednoczy się z tymi, którzy nie chcą przyjąć Jego orędzia1.

W krzyżu zatem, czyli w punkcie przecięcia się belek spotyka się samotność z otwartością, bezinteresowność z obojętnością, świętość z grzesznością. Belka poprzeczna uczy człowieka solidarności z ludźmi, a belka pionowa mówi o jedności z Ojcem. Krzyż jest znakiem tego, że Bóg cierpi z człowiekiem i nie przestaje go kochać, gdyż chce go zbawić.

Dlatego samotność w swej pedagogii posiada znaczenie zbawcze. Człowiek, uczestnicząc w niej, jednoczy się z Chrystusem, który wypełnia akt zbawienia.

Samotność, której doświadcza Jezus, przynosi zatem otwarcie na wszystkich ludzi. Będąc odrzucony przez wszystkich, paradoksalnie na wszystkich się otwiera. Zbawiciel nie umarł tylko za swoich wyznawców, ale za wszystkie dzieci Boże. Jego krzyż nie oddziela ludzi od Boga, ale raczej człowieka Bożego od tego, co w nim mniej jest bezbożne. Stwórca podkreśla tym samym logikę osoby i dobra.

${ }^{1}$ H.U. von Balthasar, Petnia wiary, tłum. J. Fenrychowa, Kraków 1991, s. 225. 


\section{Samotność na pustyni, czyli próba boskości}

Samotność, jakiej doświadczał Jezus na krzyżu, łączy się z Jego samotnością na pustyni przed oficjalną działalnością ewangelizacyjną. Zbawiciel nie poszedł tam po to, by odnaleźć siebie, ale stawić czoło historii. Ta czterdziestodniowa obecność przywołuje od razu pamięć o Izraelitach, którzy przez czterdzieści lat maszerowali do Ziemi Obiecanej przez pustynię. Zmagali się oni z propozycją Boga, narzekając i jęcząc na różne niewygody. Pragnienie wody, głód oraz zmęczenie były przyczyną ich przekleństw.

Z Ewangelii dowiadujemy się, że samotność Jezusa jest przerwana rozmową i walkąz diabłem, odwiecznym wrogiem Jego i człowieka. Jezus jednak dobrze rozeznaje się $\mathrm{w}$ działaniu kusiciela, stąd jest zorientowany, jak z nim skutecznie walczyć. $W$ trzech pokusach, jakimi posługuje się diabeł, odbijają się wszelkie inne pokusy, poprzez które kuszeni są ludzie.

Wobec pierwszej pokusy diabelskiej, by kamienie zmienić w chleb, Zbawiciel wskazuje, iż istnieją wartości wyższe, które są człowiekowi potrzebne. Kto pragnie być Jego uczniem, winien wyzbyć się adoracji świata i przylgnąć do Niego. Człowiek nie może żyć tylko chlebem, bo wtedy jest oderwany od Boga i upodabnia się do zwierzęcia. Wielkie miasta świata, gdzie człowiek w pogoni za zarobkiem staje się homo consumator, odnajdują w materii drogę swojego pozornego sukcesu i szczęścia. Świat, który eliminuje Boga, a troszczy się tylko o rzeczy materialne, zawsze ponosi klęskę.

W drugiej pokusie diabeł odzywa się jak wytrawny teolog, doskonale znający Pismo Święte. Wymaga od Jezusa próby polegającej na tym, by rzucił się z narożnika świątyni, uratował się, aby świat zobaczył Jego wielkość. Jezus nie tylko w oczach szatana, ale przede wszystkim tych, których pragnie nawrócić, postrzegany jest jako kaznodzieja, ale nie Bóg. Do dziś stosują tę praktykę ci, dla których bożkiem stał się rozum, by pokazać Pana jako zwykłego kaznodzieję. Chodzi tu po prostu o to, by Bóg-człowiek dostosował się do świata, a nie na odwrót.

Wreszcie trzecia pokusa. Diabeł stawia się w roli właściciela świata, obiecując dać Jezusowi wszystkie swoje kosztowności. Stawia taki warunek: Jezus musi przed nim uklęknąć. Zbawiciel niweczy diabelskie plany. Tym, przed kim można klękać, jest tylko Pan Bóg, Stwórca nieba i ziemi, do którego należą wszelkie bogactwa. „Dana mi jest wszelka władza, w niebie i na ziemi" - wyznaje Jezus. Pokusa ta uświadamia, że diabłu nie chodzi o jakieś rzeczy drugo- czy trzeciorzędne, ale rości on sobie prawo do wszystkich królestw świata. Dlatego Jezus przepędza diabła, podobnie jak przepędził go Ojciec z nieba. Wniosek stąd taki: pokusy, z którymi zmagał się Jezus i z którymi zmaga się każdy człowiek, otwierają drogę do nieba. 


\section{Samotność z Bogiem zaspokojeniem ludzkich pragnień}

Dlaczego ludzie boją się samotności? Bo nie chcą poznać prawdy o sobie samych. Tymczasem człowiek bez samotności i prawdy nie może być szczęśliwy. Szczęście bowiem polega na tym, by pragnąć Boga, który winien spocząć w człowieczym sercu.

Historia Kościoła przypomina wiele osób, którzy poprzez modlitwę łączyli się w samotności z Bogiem i stali się ludźmi czynu. Św. Pio z Pietralciny z dala od fleszy i ciekawskich tłumów pisał nie tylko o swych doświadczeniach mistycznych, ale również o wątpliwościach i lękach zrodzonych w opuszczeniu i samotności. Nie zapomniał o tym, by doradzać, pocieszać, podnosić na duchu, wskazywać drogę do wewnętrznego spokoju, zalecając wyciszenie i medytację. Uczyl, że by wejść do słodkiej ziemi Bożej, trzeba przejść przez pustynię "gorzkich ziół".

Gdy człowiek otwiera się na Boga, samotność jest twórczym czynnikiem w duchowym rozwoju. Jest ona wpisana w świętość tych, którzy chcą kroczyć po ścieżkach Pana Boga.

Czy pozostając $\mathrm{w}$ świecie i pracując $\mathrm{w}$ fabryce, można wieść życie pełne skupienia, modlitwy i życzliwości dla ludzi? Jest to przykład tak zwanego monastycyzmu duchowego ${ }^{2}$. W obecnych czasach uprawiają go Wspólnoty Jerozolimskie założone przez księdza Pierre'a-Marie Delfieux. W przeciwieństwie do zakonów klauzurowych, ich członkowie nie izolują się od ludzi, ale świadomie udają się na "pustynie wielkich miast”, chcąc tam szukać Boga i dawać o Nim świadectwo. Założyciel Wspólnot... podaje podstawowe prawo: "Jedynym, który ewangelizuje, jest Pan, trzeba Mu tylko na to pozwolić - najpierw w samych sobie, aby mógł zająć całą naszą wewnętrzną przestrzeń" świecać, promieniować i mówić coś innym. A wówczas nas także ewangelizuje, bo przez swą obecność sprawia, że stajemy się siostrami i braćmi człowieka" 4 .

Wspólnoty te, znajdując się w sercu miast, nie wymagają zerwania ze światem, ale mówią o Bogu poprzez liturgię, życie nacechowane braterstwem, świadectwem pracy oraz wychodzeniem naprzeciw potrzebom ludzi szukających pomocy i uspokojenia. Dawną formę ucieczki od świata na

\footnotetext{
2 W. Hryniewicz, Chrześcijaństwo nadziei, Kraków 2002, s. 206.

${ }^{3}$ Bóg w sercu miasta. Z o. Pierre-Marie Delfieux rozmawia s. Kinga Strzelecka OSU, „Tygodnik Powszechny", nr 22 z 2 czerwca 1996 r., s. 10.

4 Ibidem.
} 
pustynię lub za klauzurę zajmuje świadoma obecność pośród ludzi, otwartość i bliskość. Samotność bowiem ze swej istoty nie zależy od miejsca, ale od tego, jak przeżywamy nasze życie. Warto by się zasłuchać w ich duchowość, aby ci, którzy nie mogą sobie poradzić ze złem tego świata, dostrzegli w nich iskrę nadziei na swoje bolączki i trudności współczesnego życia.

\section{Samotność pomocą we wzroście w świętości}

Samotność zewnętrzna, czyli życie pustelnicze albo klauzurowe, służy przede wszystkim samotności wewnętrznej. Jest to droga do poznania Boga i otwarcia się na bliźniego oraz stopniowe rozumienie swojej misji w świecie. Samotność jest podstawą wzrostu autentycznego powołania. Gdy człowiek jej doświadczy, uczy się bolesnego uwolnienia własnej natury od egoizmu i koncentrowania się na Bogu. Otwiera się na Tego, który przemawia z głębokości jego sumienia. Zgodnie z duchowym prawem, im więcej doświadczy ciężaru samotności, tym bardziej liczy na Boga. Pustynia i jej rzeczywistość najlepiej oddaje dramatyzm miejsca, ale dla tych, którzy chcą spotkać Boga, pozostaje darem ciszy i radykalnego wyboru w imię słów Apokalipsy: „Obyś był zimy albo gorący!” (Ap 3,15).

W samotności pustyni bowiem poznaje się Boga, własną kruchość i grzeszność, ale też zakusy szatana pragnącego zniszczyć dzieło Boże. Pustynia to miejsce próby: ujawnia to, co $\mathrm{w}$ człowieku najgłębsze zarówno w dziedzinie zła, jak i dobra. Dopiero tu w ogniu samotności, bez pomocy innych zaczyna się rozumieć przerażającą prawdę o własnej słabości i grzeszności oraz wezwanie Chrystusa do przyjęcia postawy dziecka trzymającego się ufnie ręki Ojca. Dar pustyni albo przymnaża człowiekowi wiary, albo go czyni bluźniercą. Szatan wykorzystuje najmniejsze załamanie człowieka, by doprowadzić go do buntu. Kto wytrwa, radykalnie się zmieni, bo pozna prawdę o sobie i o Bożej miłości, która wzywana - zawsze przychodzi z pomocą.

Samotność zapewnia uwolnienie duszy od nieuporządkowanych pragnień, by mogła skupić swe władze psychiczne, umysłowe, duchowe i trwać w obecności Boga. Tę obecność znajduje się w modlitwie, która jest kluczem do ukrytych drzwi Boskiej mocy i twórczego przebywania ze Stwórcą. Dzięki niej człowiek wyzbywa się lęku, by opuścić świat doświadczeń zmysłowych i psychicznych, utwierdzonych być może wcześniej w przekonaniu o samowystarczalności. Modlitwa pozwala dostrzec wydarzenia we właściwej perspektywie oraz dać spokój i bezpieczeństwo; niszczy wszelką 
sztuczność i iluzję, a dzięki wyzwolonej energii pozwala poznać Boży zamysł. Dzięki niej człowiek przechodzi pustynię oczyszczeń i zaznaje smutku Jezusa konającego w Ogrójcu, czyli przekracza naturalne ograniczenia i wchodzi w życie Boga.

W samotności odbytej na pustyni, albo na jakimś odosobnionym miejscu, człowiek w asystencji Ducha Świętego odkrywa pedagogię Jego kierownictwa. Gdy ktoś nauczy się tej sztuki, na zawsze pozostanie Bożym ekspertem, a jego rady staną się punktem odniesienia dla tych, którzy zechcą skorzystać $\mathrm{z}$ jego pomocy. Kto nie osiągnął doskonałości, wyrażonej w ciągłych wysiłkach, nie może również stawiać czoła życiu. Trafnie na ten temat pisze św. Jan od Krzyża, dla którego milczenie nie tylko oznacza wyrzeczenie się, zapomnienie o sobie, ale wyklucza ono też religijną niedojrzałość i naiwną emocjonalność, wzmaga wiarę, ucisza sprzeciw rozumu i woli w sytuacjach wymagających pokory. Jak pisze:

Jeśli dusza nie porzuci naturalnego sposobu myślenia, nie będzie mogła przyjąć tego dobra inaczej, jak tylko sposobem naturalnym, czyli nie przyjmie go wcale i pozostanie w swym działaniu naturalnym [...]. Dla jego przyjęcia musi być całkowicie z niego wyzuta, wolna, spokojna, cicha i pogodna [...]. Jakakolwiek myśl, rozważanie czy upodobanie, na którym by się chciała oprzeć, przeszkadzałoby jej, niepokoiło i rozpraszało w tym głębokim milczeniu, jakie winna zachować w swych zmysłach i duchu dla usłyszenia głębokich i delikatnych słów, które mówi Bóg do jej serca w tej ciszy, jak to sam wyraził przez Ozeasza $(2,14)$. W największym więc spokoju i uciszeniu powinna bacznie słuchać, co mówi do niej Pan Bóg, gdyż pokój przemawia w tej samotności ${ }^{5}$.

Językiem bardziej filozofii niż mistyki na temat samotności pisze również św. Edyta Stein, w zakonie - siostra Teresa Benedykta od Krzyża:

Osobowe ja człowieka jest w najgłębszym wnętrzu duszy - w najwłaściwszym sensie - u siebie. W pełni rozporządza skupiona mocą duszy i może swobodnie nią władać. Jest tedy najbliżej sensu wszystkiego, co się dzieje, otwarte na stojące przed nim wymagania i najbardziej sposobne do właściwej oceny ich znaczenia i doniosłości. [...] Jedynie taki człowiek umie należycie, według ostatecznej miary, ocenić ich właściwą wagę i stosownie ustalać swoją postawę. I tylko dusza takiego człowieka znajduje się na drodze ku ostatecznej formacji i doskonałości swojego istnienia ${ }^{6}$.

Jeszcze przed swym nawróceniem, Stein myślała, że:

5 Św. Jan od Krzyża, Żywy płomień miłości, tłum. B. Smyrak, Kraków 2003, 3,34.

${ }^{6}$ E Stein, Byt skończony a byt wieczny, przeł. J.I. Adamska, Kraków 1995, s. 441. 
prowadzić życie religijne oznacza porzucić wszystko, co ziemskie, i żyć tylko myślami o rzeczach Bożych. Stopniowo jednak zrozumiałam, że na tym świecie żąda się od nas czegoś innego; nawet wiodąc życie kontemplacyjne, nie wolno zrywać kontaktu ze światem. Sądzę nawet, że im głębiej ktoś zanurzył się w Bogu, tym więcej, w tym samym duchu, musi „wyjść z siebie”, to jest wejść w świat, aby nieść mu życie Boże ${ }^{7}$.

Samotność uczy, że trzeba co dnia ponawiać decyzję, aby nic nie widzieć, nie słyszeć i nie zatrzymywać się na niczym, co mogłoby odwieść serce od obcowania z Bogiem.

\section{Samotność wyjściem ku wspólnocie}

Samotność nie ma nic wspólnego z formami izolacji, z pysznym oddaleniem od społeczności, ale jest wyjściem ku wspólnocie. Widać to najpełniej w życiu trynitarnym samego Boga. Sam Bóg jest Samotnością i jednocześnie Wspólnotą - Trójcą Osób przenikających się w niewyobrażalnej miłości. Biblia ukazuje Boga dla nas i ze względu na nas. Nie zna Boga w sobie i dla siebie, Boga, który jest zamknięty w sobie i dla siebie. Jego istnienie wypływa nie tyle z myślenia, ile z miłości.

Człowiek stworzony na "obraz Boga” potwierdza, że również w jego życiu samotność i wspólnota wzajemnie warunkują się i współkonstytuują. Inaczej mówiąc: jest on dynamicznie ukierunkowany ku Bogu i ku innym. Wyrazem tego wertykalnego ukierunkowania człowieka są dwa przykazania: miłości Boga i bliźniego. Napięcie między samotnością a wspólnotą zmusza człowieka do wyboru. Jeśli stanie się dyspozycyjny wobec Boga, wejdzie do wspólnoty z innymi. Takie jest też prawo rozwoju duchowego: im bardziej ktoś zanurzył się w Bogu, tym bardziej musi wyjść z siebie. Gorzką samotność zamienia wówczas w przyjaźń, którą odczytuje jako wyraz woli Bożej i znak powołania.

Samotność jest wielkim darem Ducha Świętego. Samotne godziny zasłuchania w Słowo Boga doprowadzają w końcu do miejsca, z którego można nawiązywać kontakty ze wszystkimi. Nic dziwnego, że miejsce, w którym mieszka samotnik, staje się ośrodkiem częstych odwiedzin osób szukających u niego porady i pociechy. Chociaż ci, którzy doświadczają takich wizyt, mogą czuć się czasami udręczeni, ponieważ nie mają chwili spokoju, miłość s. 87 .

7 Eadem, Autobiografia. Wybór pism duchowych, tłum. J.I. Adamska OCD, Kraków 1977, 
ku Bogu zmusza ich do nieustannej weryfikacji swoich postanowień i pytania: Kto pomoże przychodzącym braciom?

Niewielu ludzi doświadcza samotności rozumianej po chrześcijańsku. Boją się ją przyjąć, gdyż myślą, że coś stracą. Ci jednak, których Bóg wysyła na pustynię, powołani są do realizacji misji. Wzorując się na Chrystusie, stają się prawdziwymi Jego uczniami, uczestnicząc w zbawieniu siebie i tych, których Bóg postawił na drodze ich życia.

\section{Salutary dimension of soltitude and its consequences for a Christan}

\section{Summary}

Solitude for Christians is not a burden but an indispensable dimension of maturing to sanctity. It results from the life of Christ who did not only experience loneliness in the desert and on the cross, but made it something necessary. In solitude, the cross of Christ is shown as openness to all in the realization of love. Connecting them with the solitude of Christ it is easier to bear al kindly of difficult experiences inconveniences as well as to help those who cannot cope with them. 